Оригинални научни рад

341.645.2:341.24

doi:10.5937/zrpfns51-15970

Rodoljub M. Etinski, Ph.D., Full Professor

University of Novi Sad

Faculty of Law Novi Sad

R.Etinski@pf.uns.ac.rs

\title{
INTERPRETATION OF SOME BILATERAL TREATIES BY THE INTERNATIONAL COURT OF JUSTICE
}

\begin{abstract}
The text analyzes interpretations of bilateral treaties in three cases decided by the International Court of Justice in the period of 2009 to 2011. As the interpretation of the treaties was performed by applying the same rules laid down in Article 31 and 32 of the Vienna Convention on the Law of Treaties, it includes the same or similar factors and methods. Specific characteristics of each case, in particular the specific characteristics of treaties, resulted in certain differences. The range of factors used in interpretation of a treaty governing a unique issue and the range of factors used in interpretation of a treaty whose object belongs to the class of objects of an area of international law are not the same.
\end{abstract}

Keywords: interpretation; bilateral treaties.

\section{INTRODUCTION}

The text explores how the International Court of Justice (hereinafter: the Court) interpreted bilateral treaties in three cases decided from 2009 to 2011. ${ }^{1}$ The Court applied the rules on interpretation of international treaties, laid down in Articles 31 and 32 of the 1969 Vienna Convention on the Law of Treaties (hereinafter: the Vienna Convention). Interpretation precedes the application of a treaty. In judicial proceedings the Court interprets a treaty to resolve a dispute related to the treaty. In substance an interpretation consists of collecting information related to a treaty, in a way foreseen by the rules on interpretation, to answer the issue submitted to the Court. The rules on interpretation contain a set of obligatory

\footnotetext{
${ }^{1}$ This research has been rendered in the framework of the research project "Legal Tradition and New Legal Challenges" financed by the Faculty of Law of the Novi Sad University.
} 
instructions as to where and how to collect information for the interpretation of a treaty. ${ }^{2}$ In general, Articles 31 and 32 of the Vienna Convention refer to manifestations of intention of the parties to a treaty, to expressions of understanding the text of a treaty by the parties. and to circumstances that influence the intention or understanding of the parties as relevant for the interpretation of a treaty. The other set of instructions relate to methods that should be used in collecting and evaluating information and building an interpretation. As the interpretation is performed by the application of the same rules on interpretation, it is substantially the same process in each case. However, the specific characteristics of the case may have some bearing on some elements of interpretation. ${ }^{3}$

The purpose of this text is to ascertain whether the specific characteristics of the cases caused some differences in interpretation. After a short review of the considered cases, an analysis of interpretation of the bilateral treaties will commence. This paper will conclude by establishing what exactly was equal in three cases of interpretation and conversely what appears to have been different.

\section{A SHORT OVERVIEW OF THE CASES}

\subsection{Navigational and Related Rights}

Costa Rica and Nicaragua were founded on the territory of the former Spanish colony in Central America in 1821. After the war in 1857 the two countries concluded the Treaty of Limits in 1858 determining their common border and the navigational régime on the San Juan River. The Treaty established the sovereignty of Nicaragua over the river and the right of free navigation "con objetos de comercio" in favour of Costa Rica. ${ }^{4}$ Differences between the parties about the validity of the Treaty and about the right of the war ships and vessels of the Revenue Service of Costa Rica to navigate on the river were submitted to the President

${ }^{2}$ R. Etinski, Means of Interpretation and their Interrelationship, Collected Papers, Novi Sad Faculty of Law, 1/2016, pp. 9-37; E. Villiger, The Rules of Interpretation: Misgivings, Misunderstandings, Miscarriage? The "Crucible" intended by the International Law Commission, in E. Cannizzaro (ed.), The Law of Treaties Beyond the Vienna Convention, 2011, 108-114; R. Gardiner, Treaty Interpretation. Oxford, 2008, pp. 141-298; U. Liderfalk, Is the Hierarchical Structure of Article 31 and 32 of the Vienna Convention Real or Not? Interpreting the Rules of Interpretation, Netherlands International Law Review, 1/2007, at 133-154.

${ }^{3}$ The issue of relevance of specific characteristics of a treaty for its interpretation has been discussed within the International Law Commission but, for the time being, the Commission has not taken its position. Report of the ILC, 2016, p. 131, para. 16. See also S. Djajić, Fragmentacija međunarodnog prava i specijalni pravni režimi, Zbornik radova Pravnog fakulteta u Novom Sadu, 2/2016, str. 431-459.

${ }^{4}$ Dispute regarding Navigational and Related Rights (Costa Rica v. Nicaragua), Judgment, I.C.J. Reports 2009, para. 19. See the review of the judgment by Eirik Bjorge, International Court of Justice, Case concerning the Dispute regarding Navigational and Related Rights (Costa Rica v. Nicaragua) Judgment of 13 July 2009, International and Comparative Law Quarterly, 2011, pp. 271-279. 
of the United States, Grover Cleveland as an arbitrator. In 1888, the arbitrator President Cleveland decided that the Treaty was valid and that the right of free navigation, as established in Article VI of the Treaty did not cover the war ships but it authorized vessels of the Revenue Service to navigate on the river. ${ }^{5}$ Without consulting Costa Rica, as it was required by Article VIII of the Treaty of Limits, Nicaragua concluded a Treaty with the United States on the construction of an inter-ocean canal through the San Juan River. Costa Rica brought the case to the Central American Court that declared a breach of the Treaty by Nicaragua in 1916. ${ }^{6}$ In the 1980-s Nicaragua had begun to impose restrictions on navigation of the Costa Rican official vessels. The restrictions caused a dispute between the two neighbors. Having not been resolved in throughout a lengthy period, Costa Rica finally brought the dispute before the Court on 29 September 2005. By the judgment of 13 July 2009, the Court had decided the case.

\subsection{Pulp Mills on the River Uruguay}

By the bilateral Treaty concluded at Montevideo on 7 April $1961^{7}$ Argentina and Uruguay established their common border on the River Uruguay and obliged themselves in Article 7 of the Treaty to create an international régime for the river. Article 7 was fulfilled by conclusion of the Statute of the River Uruguay in 1975 that provides inter alia for environmental protection of the river and established the Commission which has had an important role in environmental protection. Authorization of two projects of pulp mills on the bank of the river by Uruguay caused some differences between the two parties concerning the international legality of the authorization. Having not been resolved trough bilateral negotiations, Argentina brought the dispute before the Court on 4 May 2006. The Court resolved the differences by the judgment delivered on 20 April $2010 .{ }^{8}$

\subsection{Application of the Interim Accord}

To mitigate the harsh consequences that the Greek disagreement with the constitutional name of Macedonia had produced to their bilateral relations and to the international position of Macedonia, the two States agreed to some mutual concessions by the Interim Accord, signed on 13 September 1995. Inter alia, by Article 11 (1) of the Accord Macedonia accepted to be named in international organizations under the temporal name, determined in Security Council resolution

${ }^{5}$ Ibid., para. 20.

${ }^{6}$ Ibid., para. 22.

${ }^{7}$ UNTS, Vol. 635, No. 9074, p. 98.

8 Pulp Mills on the River Uruguay (Argentina v. Uruguay), Judgment, I.C.J. Reports 2010, p. 14. See the review of the judgment by Cymie R. Payne, Pulp Mills on the River Uruguay (Argentina v. Uruguay), American Journal of International Law, 1/2011, pp. 94-101. 
845 (1993), and Greece consented not to object to the admission of Macedonia to international organizations.

Macedonia applied for the membership of NATO under its constitutional name. Considering that such an application was not in compliance with Article 11 (1) Greece obstructed the admission at the Bucharest Summit of 2008. On 17 November 2008 Macedonia initiated proceedings against Greece before the Court claiming that by the obstruction Greece violated its obligation under Article 11 (1). The Court pronounced the judgment on 5. December 2011.9

\section{APPLICATION OF THE RULES ON INTERPRETATION OF INTERNA- TIONAL TREATIES IN THE CONSIDERED CASES}

\subsection{Application of the rules on interpretation in the Navigational and Related Rights case}

Many differences in respect of interpretation of the Treaty of Limits between Costa Rica and Nicaragua can be assembled around three main issues: the extent of Costa Rica's right of free navigation on the San Juan River; the extent of Nicaragua's regulatory powers over navigation of Costa Rican boats; and the right of the inhabitants of the Costa Rica river bank to subsistence fishing. ${ }^{10}$ The Court applied customary international rules on interpretation of treaties as they are expressed in Articles 31 and 32 of the Vienna Convention. Having in view the customary character of the rules, the fact that Nicaragua was not a party to the Vienna Convention and the fact that the subject-matter of interpretation, the 1858 Treaty of Limits, predated the Vienna Convention was not an obstacle for the application of the rules. The Court did not accept the proposition of Nicaragua that Costa Rica's right of navigation should have been interpreted restrictively as it limited the sovereignty of Nicaragua. ${ }^{11}$ The Court found support for such a position in the text of Article VI of the Treaty of Limits according to which the sovereignty of Nicaragua over the river was counterbalanced by Costa Rica's "perpetual" right of free navigation. The text of the Article did not give a priority to either of them. ${ }^{12}$

It seems that the principle of judicial economy determined the position of the Court concerning the basic differences between the parties related to the legal qualification of the San Juan River and the existence and applicability of the rules

${ }^{9}$ Application of the Interim Accord of 13 September 1995 (the former Yugoslav Republic of Macedonia v. Greece), Judgment of 5 December 2011, I.C.J. Reports 2011, p. 644.

${ }^{10}$ Dispute regarding Navigational and Related Rights (Costa Rica v. Nicaragua), Judgment, I.C.J. Reports 2009, para. 29.

${ }^{11}$ Ibid., para. 48 .

12 Ibid., para. 48. 
of customary international law on river navigation in a situation as it was the situation of the San Juan. Costa Rica claimed that the San Juan was an international river and that its right to navigation was based on and governed by the Treaty of Limits but also that it was grounded on and regulated by the rules of international customary law. ${ }^{13}$ Since Nicaragua has sovereignty over the San Juan, it denied an international character of the river as well as the existence of an international régime of navigation that would be applicable to rivers such as the San Juan and asserted that even if such régime were existent it would be superseded by the Treaty of Limits. ${ }^{14}$ Having established that the Treaty of Limits, as interpreted in light of other treaty provisions in force between the parties and relevant arbitral and judicial decisions that bound the parties, extended sufficient information for answering all questions concerning the title and extent of the right of free navigation, the Court concluded that it was not necessary to consider that had these provisions not existed Costa Rica could have relied on rules of international universal or regional custom. ${ }^{15}$ Since, even if customary rules had existed, they would have been operative in the absence of any treaty provisions. ${ }^{16}$

Costa Rica's right of free navigation has been defined by Article VI of the Treaty of Limits that states:

"The Republic of Nicaragua shall have exclusive dominium and imperium over the waters of the San Juan River from its origin in the lake to its mouth at the Atlantic Ocean; the Republic of Costa Rica shall however have a perpetual right of free navigation on the said waters between the mouth of the river and a point located three English miles below Castillo Viejo, [con objetos de comercio], whether with Nicaragua or with the interior of Costa Rica by the rivers San Carlos or Sarapiquí or any other waterway starting from the section of the bank of the San Juan established as belonging to that Republic.

The vessels of both countries may land indiscriminately on either bank of the section of the river where navigation is common, without paying any taxes, unless agreed by both Governments." 17

Interpreting the Article the Court resolved some crucial differences between the parties. Some additional information for answering these crucial and other questions brought before it the Court found in other provisions of the Treaty of Limits and other legal sources. Article II established the border on the Costa Rican bank. Article IV obliged Costa Rica to contribute to the security of the river. Article VIII bound Nicaragua to consult Costa Rica before concluding any

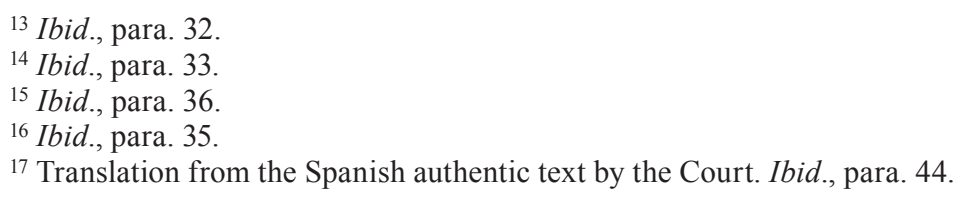

${ }^{17}$ Translation from the Spanish authentic text by the Court. Ibid., para. 44. 
agreement with a third State for canalization or transit on the river. The Court found in these Articles information necessary to reply to the questions. The Agreement concluded between the two States on 9 January 1956 related to the maximal collaboration of the parties to facilitate and expedite traffic at the San Juan River was a source of useful information. The Arbitral Award of the President of the United States, Grover Cleveland, made on 22 March 1888, and the decision of the Central American Court of Justice of 30 September 1916 that settled some differences between the parties relating to the Treaty of Limits contained some useful indications that the Court used to interpret the Treaty of Limits.

The parties understood the phrase in Article VI "con objetos de comercio" differently and consequently interpreted differently the extent of the right of free navigation. The term "objetos" has several meanings including object in the concrete and material sense and object or purpose in the abstract sense. Nicaragua opted for the first meaning and interpreted the relevant text in Article VI to mean that the right of free navigation was limited to the transport of goods for commercial exchange. Costa Rica chose the second meaning and argued that the right of free navigation was established for all commercial purposes that include not only an exchange of goods but also the transport of passengers, including tourists. ${ }^{18}$

The Court used a literal analysis of the sentence with the disputed words, another Article of the Treaty of Limits, the text of the Peace Treaty of 1857 and the official English translations of Article VI that both parties used in the arbitration of $1887 .{ }^{19} \mathrm{~A}$ literal analysis, done by the Court, has shown that attribution of a meaning of physical goods to the disputed word makes the sentence meaningless. Conversely, ascribing the meaning of a purpose to the disputed word makes the sentence quite comprehensible. Thus, a literal analysis directed the Court to the right meaning of the term. Further, the word "objetos" is used in Article VIII of the Treaty of Limits where it means "the purpose." The Court observed that fact as a confirmation that the parties understood the term in its abstract sense or, at least, that this meaning was familiar to them. In the text of the Peace Treaty of 1857 that never entered into force the same parties used terms "artículos de comercio" as a qualification of the right of free navigation. The terms mean "commercial articles" in the sense of physical goods. Consequently, when the parties intended to refer to commercial articles they used precise Spanish terms. For the purpose of arbitration in 1887 both parties sent their English translations of the Treaty of Limits to arbitrator President Cleveland and they both translated the words "con objetos de comercio" equally "for the purpose of commerce". By analyzing the literal meaning of the sentence, by reading the term in the context of other provisions of the Treaty, by contrasting it with different terms in the

\footnotetext{
${ }^{18}$ Ibid., para. 45.

${ }^{19} \mathrm{Ibid}$., paras50-56.
} 
previous treaty and by finding that two parties translated the term equally in their official English translation, the Court assembled enough information for persuasive clarification of its meaning.

Having determined that the disputed words mean "for the purpose of commerce", the Court rejected the contention of Costa Rica that Article VI established the right of free navigation for all purposes. The Court explained that such interpretation would deprive the words "for the purpose of commerce" of any effect. ${ }^{20}$ It added that the expressly designated purpose of a right excludes in principle other purposes. The Court was keeping to a variant of the principle of effectiveness - l'effet utile - and to a common standard of interpretation: expressio unius est exclusio alterius.

Then the Court turned its attention to different interpretations of the term "commerce". The parties disputed which meaning has to be given to the term, the meaning it had at the time of the conclusion of the Treaty of Limits or the meaning it has in time of the application of the Treaty? Referring to the intention of the parties as decisive for the interpretation of treaties, Nicaragua advocated the meaning existed at the time of the conclusion of a treaty since the parties had in view that meaning. However, the Court observed that States have been aware that the meaning of generic terms could evolve over time and when States enter an international arrangement for a long period it must be presumed, as a general rule, that they intended to accept the possible evolution of the meaning of such terms. The support for such a position on the issue of intertemporality the Court found in Article $31(3, b)$ of the Vienna Convention that distinguishes subsequent practice in the application of the treaty as means of interpretation allowing that subsequent practice display a tacit agreement among the parties that departs from their original intent. ${ }^{21}$ As the term "commerce" is a generic term and as the navigational arrangement established by Article VI is of unlimited duration, the Court concluded that the meaning existing at the time of application has to be given to the term "commerce" and thus it comprehended not only trade of goods but also commercial transport of passengers including tourists. ${ }^{22}$

One of the issues from the set of differences related to the extent of the right of free navigation was whether the inhabitants of the villages on the Costa Rican bank of the river can navigate by their own vessels in order to meet their needs

${ }^{20}$ Ibid., para. 61.

${ }^{21}$ See doctrinal opinions on evolutionary interpretation of international treaties: Eirik Bjorge, The Evolutionary Interpretation on Treaties, Oxford, 2014; P.M. Dupuy, Evolutionary Interpretation of Treaties: Between Memory and Prophecy, in in E. Cannizzaro (ed.), The Law of Treaties Beyond the Vienna Convention, 2011, at 126; S.C. Prebensen, 'Evolutive interpretation of the European Convention on Human Rights', in P. Mahoney at al., (eds) Protecting Human Rights: The European Perspective, 2000, 1123;

22 Dispute regarding Navigational and Related Rights, op. cit. para. 62-70. 
for everyday life, such as taking children to school or to give or receive medical treatment? Such navigation has been performed free of charge. The Court found that the right of free navigation for commercial purpose, as established by Article VI of the Treaty of Limits did not cover such navigation. ${ }^{23}$ However, the Court observed that it did not necessary mean that such navigation was deprived of any foundation in the Treaty of Limits. It was necessary, according to the Court, to consider the whole text of the Treaty and to see whether an entitlement to such navigation might be an indispensable consequence of a provision of the Treaty whose purpose was not to govern navigation. ${ }^{24}$ Having in view that Article II established the border on the Costa Rican bank of the river, bearing in mind the object and purpose of the Treaty, as set out in the Preamble and Article 1, as well as the historical background of the conclusion of the Treaty and the geography of the area, the Court was of the opinion that it could not be presumed that the parties intended to deprive the inhabitants of Costa Rican bank of the possibility to use navigation on the river for meeting their basic daily needs. ${ }^{25}$ The Court observed that it's finding that an expressly designated purpose excludes other purposes related to interpretation Article VI of the Treaty only, but that a title of the right of free navigation in favour of the inhabitants of the Costa Rican bank was derived from other provisions of the Treaty. Further, the Court stated that its interpretation of the Treaty related to the navigation of private vessels of the inhabitants of Costa Rican bank for their needs of everyday life were equally valid for the navigation of official vessels of Costa Rica for the same purpose. ${ }^{26}$ In fact, the text of the Treaty as a whole, together with the historical background of the Treaty indicated in the best case that Nicaragua did not oppose non-commercial navigation of the inhabitants of the Costa Rican bank. More reliable evidence of intention or understanding of the parties was the continuing practice of such navigation without interference of Nicaragua until 1980.

Another set of differences between the parties related to the extent of the regulatory power of Nicaragua over Costa Rica's right of free navigation. The parties agreed that Nicaragua, having sovereignty over the river, had the power to regulate navigation for legitimate public purposes but they disagreed inter alia whether the protection of the environment could be a legitimate public purpose. Having extended previously formulated concept of intertemporality, the Court stated that public interests that have to be protected through regulation "may well have changed in ways that could have never been anticipated by the Parties at the time: protecting the environment is a notable example." 27 Obviously, the position

\footnotetext{
${ }^{23}$ Ibid., para. 74, 75.

${ }^{24}$ Ibid., para. 76.

${ }^{25}$ Ibid., para. 79.

${ }^{26}$ Ibid., para. 84.

${ }^{27}$ Ibid., para. 89.
} 
of the Court was that the interpretation of an international régime, established by a treaty for an unlimited period of application, was not tied by the original intention of the parties in each specific case that might not have been foreseen by the parties at the time of conclusion and that the terms have absorbed new meaning brought by subsequent development. At the time of interpretation the general practice of States confirms that the protection of the environment had become a legitimate concern of sovereign powers. The meaning of regulatory power of Nicaragua, established by Article VI of the 1858 Treaty of Limits, had been enlarged by the spoken development. The general relevant development of the practice of States might be a circumstance that informs the parties on how to understand the meaning of terms of a treaty that govern a continuing international régime.

One of differences from that set was whether Nicaragua was obliged to notify Costa Rica of its new regulations pursuant to the San Juan River. There was no specific provision in the Treaty of Limits that would give information relevant to resolving the difference but the Court saw three factors informing it on how to model an answer. The first was found in the 1956 bilateral Treaty on the cooperation of the two parties that obliged the parties to collaborate to the best of their ability to facilitate and expedite traffic, in particular through the San Juan River. The Court considered that the 1956 Treaty implied the obligation of Nicaragua to notify the regulation to Costa Rica. ${ }^{28}$ The second and third factor came from the subject-matter and nature of the regulation. Subjugation to regulation and attainment of purposes of regulation presuppose that it is known to those that have to adhere to it. Consequently, it presupposes that Costa Rica informs its citizens about regulation after regulation was notified to it. ${ }^{29}$

The parties differed on whether Costa Rica had the right that inhabitants living on its bank of the San Juan River could fish in the river for subsistence purposes. The Treaty of Limits does not address the issue. Both parties agreed that the long lasting practice of such fishing has existed but they disputed whether an international customary rule was born in the practice. Nicaragua claimed that the practice could not be enough to be treated as a title of the right. Two factors were of importance for the Court's finding. Nicaragua tolerated the practice throughout lengthy period. It objected the first time when Costa Rica initiated the proceedings before the Court. The second factor that the Court had in view was the remoteness of the area and the small spread population that resulted in the absence of official records that could document the practice. The Court declared the existence of the customary right of Costa Rica.

\footnotetext{
${ }^{28}$ Ibid., para. 93.

${ }^{29}$ Ibid., paras 95, 96.
} 


\subsection{Application of the rules on interpretation in the Pulp Mills case}

In Pulp Mills the Court interpreted environmental provisions in the Statute of the River Uruguay. ${ }^{30}$ Argentina brought the dispute before the Court alleging breaches of environmental procedural and substantive provisions in the Statute and environmental obligations beyond the Statute by Uruguay's authorization of building pulp mills on the bank of the River Uruguay. Article 60 of the Statute limited the jurisdiction of the Court to the disputes on interpretation and application of the 1961 Boundary Treaty and the Statute, but invoking Article $31(3, c)$ of the Vienna Convention and Articles 1 and 41 (a) of the Statute, Argentina tried to extend jurisdiction of the Court to environmental treaties and general rules of international environmental law. Article $31(3, \mathrm{c})$ of the Vienna Convention instructs an interpreter of an international treaty to take into account also the relevant rules of international law applicable between the parties. Argentina claimed that Articles 1 and 41 (a) of the Statute incorporated in the Statute international obligations flowing from other environmental treaties binding on the parties. The Court accepted the relevance of the invoked provisions in respect to interpretation of the Statute only.

Article 1 in the English version of the Statute, as published in the UN Treaty Series, reads:

"The Parties agree on this Statute, in implementation of the provisions of article 7 of the Treaty concerning the Boundary Constituted by the River Uruguay, of 7 April 1961, in order to establish the joint machinery necessary for the optimum and rational utilization of the River Uruguay, in strict observance of the rights and obligations arising from treaties and other international agreements in force for each of the Parties." 31

This might mean, as it is presented, that the optimum and rational utilization of the river has to be achieved in observance of the treaties in force for each of the parties. In such a way it incorporates other treaties into the Statute. However, the authentic Spanish version of the Statute differs from the English and French translations by including the conjunction "and" before the words "in strict observance of the rights and obligations arising from treaties...". The Court found that the conjunction has connected the words "in implementation of the provisions of article 7 of the Treaty..." with words "in strict observance of the rights and obligations arising from treaties..." so that they together mean that the joint machin-

${ }^{30}$ The Statute of the River Uruguay was signed by Argentina and Uruguay at Salto (Uruguay) on 26 February 1975 and entered into force on 18 September 1976, United Nations, Treaty Series, vol. 1295, No. I-21425, p. 340. The Statute originated in Article 7 of the Treaty on the boundary between Argentina and Uruguay, signed in Montevideo on 7 April 1961. UNTS, Vol. 635, No. 9074, p. 98 .

${ }^{31}$ Pulp Mills on the River Uruguay, op. cit. para. 59. 
ery was established in implementation of Article 7 of the Boundary Treaty and other obligations arising from other treaties then in force. ${ }^{32}$ The Court added another linguistic argument in favour of such an interpretation. The Spanish original and the English and French translations are clear that refer to treaties and international agreements in force for each of the parties, not for both parties. ${ }^{33}$ That indicates, according to the Court, that the Statute refers to prior obligations of each of the parties that had some bearing on its conclusion. Thus the Court relied on the grammar in clarification of the meaning of the text.

Article 41 of the Statute states:

"Without prejudice to the functions assigned to the Commission in this respect, the Parties undertake: (a) To protect and preserve the aquatic environment and, in particular, to prevent its pollution, by prescribing appropriate rules and measures in accordance with applicable international agreements and in keeping, where relevant, with the guidelines and recommendations of international technical bodies; (b) not to reduce in their respective legal systems: 1) the technical requirements in force for preventing water pollution, and 2) the severity of the penalties established for violations; (c) to inform one another of any rules which they plan to prescribe with regard to water pollution in order to establish equivalent rules in their respective legal systems." 34

The Court noted a new difference between the Spanish original and the English translation. The words "adopting appropriate" before the words "measures in accordance with applicable international agreements..." were omitted in the English translation. Looking at the purpose and text of the Article the Court understood that the Article did not incorporate other treaties into the Statute but rather obliged the parties to pursue their regulatory powers in defined way: in compliance with applicable international agreements. ${ }^{35}$ Consequently, the Court concluded that Articles 1 and 41 (1) of the Statute, considered by Argentina as "referring clauses," did not incorporate environmental treaties into the Statute and the Court did not find anything in the Statute that had done that. The following passages will show that the Court relied on Article 31 (3, c) of the Vienna Convention and Article 41 (a) of the Statute in interpretation of the Statute but the Court said explicitly that that had not any bearing on its jurisdiction as established by Article 60 of the Statute.

Both parties agreed and the Court accepted that the Statute had to be interpreted in accordance with the rules of customary international law on treaty interpretation, as codified in Article 31 of the Vienna Convention. The Court dis-

\footnotetext{
32 Ibid., para. 59.

33 Ibid., para. 60.

34 Ibid., para. 61.

35 Ibid., para. 62.
} 
tinguished a means of interpretation laid down in Article $31(3, c)$ of the Vienna Convention: relevant rules of international law, in this case environmental law, applicable between the parties. ${ }^{36}$ The Court amplified the effect of that means referring to Article 41 (a) of the Statute that requires the parties in pursuing their regulatory activities to follow inter alia "the guidelines and recommendations of international technical bodies." The Court consulted findings on general principles and rules of environmental law in its previous judgments, relevant international treaties, harmonic practice of States, guidelines of the River Commission exposed in its Digest on the uses of the waters of the River Uruguay to collect information necessary to interpret the Statute and thus to answer the submitted questions.

The principle of effectiveness played a role in interpretation of procedural provisions of the Statute. The Court did not explicitly mention principle of effectiveness that is a part and parcel of the principle of good faith but it seems that the principle of effectiveness informs some of the Court's answers. The parties disputed inter alia about the timing of some procedural steps such as when the party was obliged to inform the River Commission on the planned activity or when the party was allowed to issue an initial environmental authorization. The provisions of the Statute did not answer the questions but the Court replied in such a way as to enable that in the Statute foreseen procedure has been capable of producing the designed effect. The Court found that Uruguay violated procedural obligations under the Statute.

Interpreting substantive provisions of the Statute to ascertain whether Uruguay violated them, the Court drew information from the text of the Statute, from the coordinated position of the parties reached through the River Commission and from the national regulation of each party promulgated in compliance with Article 41 (1) of the Statute.

Interpreting the obligation to protect and preserve the aquatic environment in Article 41 (a) of the Statute, the Court considered that it included the obligation of making an environmental impact assessment. ${ }^{37}$ The text of the Statute did not mention the environmental impact assessment but the parties agreed that they were obliged to render an environmental impact assessment when the planned activity created a risk of harm for shared resources. ${ }^{38}$ The Court stated that: "the obligation to protect and preserve, under Article 41 (a) of the Statute, has to be interpreted in accordance with a practice, which in recent years has gained so much acceptance among States that it may now be considered a requirement under general international law to undertake an environmental impact assessment where there is a risk that the proposed industrial activity may have a significant adverse

\footnotetext{
${ }^{36}$ Ibid., para. 65 .

${ }^{37}$ Ibid., para. 204.

${ }^{38}$ Ibid., para. 203.
} 
impact in a transboundary context, in particular, on a shared resource." ${ }^{39}$ In the context of that argument the Court recalled its finding in Dispute Regarding Navigational and Related Rights on a capability of the meaning of generic terms to evolve over time. The Court ascertained the existence of a general harmonious practice and observed that the practice reached the level of the rule of general international law applicable between the parties and thus by virtue of Article 31 $(3, c)$ of the Vienna Convention relevant for interpretation of the Statute. It seems that the Court considered also that an environmental impact assessment was a kind of manifestation of due diligence and the duty of vigilance and prevention. ${ }^{40}$

However, the Statute and general international law did not establish the scope and content of an environmental impact assessment. Argentina and Uruguay were not parties to the Espoo Convention. The relevant UNEP Goals and Principles that were applicable between the parties in accordance with Article 41 (a) of the Statute were not of significant help since they did not specify minimal content of the assessment. Having established that the relevant information could not be found in available sources of relevance for the parties, the Court concluded that it is for each State to define the content of an environmental impact assessment in its internal legislation or procedures..$^{41}$ Having noted that, the Court investigated undisputed element of the content of environmental impact assessment such as whether Uruguay fulfilled the obligation to explore alternative sites of the plant in view of receiving capacity of the river and the obligation to consult the riparian population at risk to be affected. The content of an obligation to prevent pollution of the river was substantiated manly by standards established by the River Commission and national regulations of the parties. The Court did not find a failure of Uruguay to respect its substantive obligations under the Statute.

Having in view issues and arguments brought before it, the Court interpreted provisions of the Statute to clarify not only meaning of the provisions including their content but also to explain mutual interdependence of the procedural obligations and the substantive obligations, legal character of obligations established by the Statute as well as the effect of later agreements between the parties to the Statute. In 2004, by common understanding, the parties agreed procedure that Uruguay interpreted as overtaking the procedure foreseen by the Statute. Since Uruguay did not fulfill the obligation accepted by the understanding, the Court found that the understanding did not derogate the procedure established by the Statute.

\footnotetext{
${ }^{39}$ Ibid., para. 204.

${ }^{40}$ Ibid., paras 204, 209.

${ }^{41}$ Ibid., para. 205.
} 


\subsection{Application of the rules on interpretation in the Application of the Interim Accord case}

The issue of the merits was "whether the Respondent failed to comply with the obligation under Article 11, Paragraph 1, of the Interim Accord?" The issue consisted of two differences between the parties: the first related to a meaning of the words "not to object" and the second concerning a meaning of the exception to the obligation not to object. The text of Article 11 (1), as presented in the judgment, reads:

"the Party of the First Part [the Respondent] agrees not to object to the application by or the membership of the Party of the Second Part [the Applicant] in international, multilateral and regional organizations and institutions of which the Party of the First Part is a member; however, the Party of the First Part reserves the right to object to any membership referred to above if and to the extent the Party of the Second Part is to be referred to in such organization or institution differently than in paragraph 2 of United Nations Security Council resolution 817 (1993)". 42

The parties differed on the meaning of the words "not to object". The applicant advocated an extensive interpretation and the respondent a restrictive interpretation having in view that the obligation restricts its sovereign right. The Court did not accept that special rules of interpretation should be applied to a treaty that "limits a right that a party would otherwise have". ${ }^{43}$ It found nothing in the text of the provision neither any other indication that the parties intended to exclude from the obligation "not to object" international organizations that, like NATO, do not have formal procedure of voting for the admission of a new member. Consequently, the obligation "not to object" cannot be reduced to negative vote.

The next difference between the parties was whether the objection of the respondent to the admission of the applicant to NATO had its justification in the exception provided for in second clause of Article 11 (1) by which the responded reserved the right to object "if and to the extent the Party of the Second Part is to be referred to in such organization or institution differently than in paragraph 2 of United Nations Security Council resolution 817 (1993)" The applicant applied for the membership in NATO under its constitutional name "the Republic of Macedonia," not under the name indicated in paragraph 2 of UN Security Council resolution 817 (1993) "the former Yugoslav Republic of Macedonia" considering that the resolution and Article 11 (1) do not oblige it to use the provisional name designated by the resolution. It interpreted Article 11 (1) to mean only that organs of an international organization have to address it under the provisional

${ }^{42}$ Application of the Interim Accord of 13 September 1995, op. cit., para. 62.
${ }^{43}$ Ibid., para. 70. 
name designated by the resolution. Interpreting Article 11 (1) and the resolution in opposite way, the responded asserted that the intent of the applicant to name itself differently than it was designated by the resolution and prospect that some members of NATO might use also the applicant's constitutional name had activated the exception and empowered the responded to object. The respondent explained that the clause spoke on naming the applicant "in" an organization, not "by" an organization. Invoking effet utile of the words "and to the extent" the responded claimed naming the applicant differently that it was designated by the resolution by officers or members of an organization can activate the reserved right to objection.

The Court applied Articles 31 and 32 of the Vienna Convention to interpret the disputed text. It began by considering the ordinary meaning of the terms in their context and in light of the object and purpose of the Interim Agreement. ${ }^{44}$ In fact, the Court began by the observation that the passive voice of the second clause of Article 11 (a) could not be reconciled with the respondent's interpretation that the disputed clause addressed not only an organization but also the applicant. Concerning the phrase "and to the extent" the Court considered that it can have effet utile even if it does not mean that the reserved right to object is triggered if not only an organization but also others use the constitutional name. It will have effet utile, according to the Court, if means the responded has the right to object so long as an organization uses the constitutional name..$^{45}$

As the disputed clause refers to paragraph 2 of UN Security Council resolution 817 (1993), the Court explored whether the text of the paragraph extended information that could help the Court to answer the question. The Security Council recommended by the resolution to the General Assembly to admit the applicant to the membership in the UN and that the applicant will be "provisionally referred to for all purposes within the United Nations as 'the former Yugoslav Republic of Macedonia." "46 Bearing in mind that the resolution was a recommendation of the Security Council on the admission of the applicant to the UN sent to the General Assembly to be effectuated, it might be argued, according to the Court, that paragraph 2 of the resolution was directed to the General Assembly rather than to individual Members. On the other hand, the Court noted that the text of paragraph 2 was very broad - "for all purposes" - and could be understood to address all members, including the applicant. ${ }^{47}$

Further, the Court considered the context of Article 11 (1), the overall structure of the Interim Accord and its object and purpose as well as a subsequent practice in the application of Article 11 (1). Article 1 (1) of the Interim Accord

\footnotetext{
44 Ibid., para. 91,

45 Ibid., para. 92.

46 Ibid., para. 93.

47 Ibid., para. 93.
} 
declares that the respondent recognizes the applicant as an independent and sovereign State under the provisional designation. There is no provision in the Interim Agreement requiring the applicant to name itself under the provisional designation. Quite the opposite, the "Memorandum on 'Practical Measures' Related to the Interim Accord," concluded by the parties in time of the entry into force of the Interim Agreement explicitly allows the applicant to name itself "the Republic of Macedonia" in the communication with the respondent. Obviously, since the entry into force of the Interim Agreement, the responded did not ask the applicant not to use its constitutional name in all circumstances. ${ }^{48}$

The Court considered the method of drafting the Interim Agreement and noted that when parties wanted that the applicant change something in its behavior they explicitly said it. Article 7 (2) obliges the applicant to change the symbol that it previously used on its flag. Article 6 formulates other obligations of the applicant in respect of interpretation of certain provisions of its constitution. When drafting the Interim Agreement, the parties were aware that the applicant had constantly used its constitutional name in the UN but they did not insert an obligation to cease to do so. ${ }^{49}$

The common view of the parties was that the Interim Accord was a comprehensive exchange serving a few purposes including a normalization of mutual relations, bilaterally and in international organizations. Thus, Article 11 (1) provides an exchange of some benefits facilitating the normalization of relations between the parties in international organizations. Having in view such a structure, the object and purpose of the Interim Agreement, the Court concluded that the parties would not establish such significant new constraint on the applicant as the requirement not to name itself by its constitutional name in international organizations by mere implication in Article 11 (1)..$^{50}$

Invoking Article $31(3, b)$ of the Vienna convention, the Court explored the practice in the application of Article 11 (1). The practice informs that the respondent did not object to the admission of the applicant to international organizations although the applicant used its constitutional name. Since 2004, when the Interim Agreement entered into force, the applicant was admitted to 15 international organizations applying for the membership under its constitutional name. The responded did not object, except in two cases in the Council of Europe, but not in the occasion of admission but later. Equally, the applicant participated in various forms of co-operations with NATO under its constitutional name without objection of the respondent. ${ }^{51}$

\footnotetext{
48 Ibid., para. 95.

${ }^{49}$ Ibid., para. 96.

${ }^{50}$ Ibid., para. 97.

${ }^{51}$ Ibid., paras 99,100.
} 
The parties provided the Court with extensive evidence of the travaux preparatoires of the Interim Accord and of resolution 817. Having been convinced that applied means of interpretation provided it with enough reliable information to answer the raised question, the Court considered that it was not necessary to explore this evidence. It seems that the Court treated this note as the application of Article 32 since it said in a previous paragraph of the judgment that it would apply Articles 31 and 32 of the Vienna Convention.

Considering jurisdictional objection of Greece, the Court stated that the exception of the jurisdiction of the Court concerning the name of the Applicant, as established in Article 21 (2) of the Interim Accord, cannot be interpreted broadly. ${ }^{52}$ The text of Article 21 (2) in context of the text of Article 5 (1) of the Interim Agreement clearly defines the exception..$^{53}$ The broad interpretation of the exception would be contrary to the purpose of the Interim Agreement to stabilize the relations between the parties in the course of the resolution of the name difference. ${ }^{54}$

\section{A COMPARATIVE ANALYSIS OF THE CASES}

\subsection{Substantially equal approach of the Court to the interpretation in three cases}

The Court referred to Article 31 of the Vienna Convention in all three cases. In Navigational and Related Rights and in Application of the Interim Accord the Court referred also to Article 32 of the Vienna Convention. In two cases - Navigational and Related Rights and Pulp Mills - customary rules on interpretation of international treaties, as they have been reflected in corresponding Articles of the Vienna Convention, were applied. In Pulp Mills the Court found support in Article 41 (a) of the Statute of the River Uruguay to use the Digest on the uses of the waters of the River Uruguay of the River's Commission for substantiating some provisions of the Statute.

The principle of good faith carries a reliable presumption that the text of a treaty expresses intention of the parties and consequently it is expected that the Court is searching for information it needs for interpretation in the text of a treaty. Such in Navigational and Related Rights the Court stated: "A treaty provision ... must be interpreted ... in accordance with the intentions of its authors as reflected by the text of the treaty and the other relevant factors in terms of interpretation." 55

\footnotetext{
52 Ibid., para. 34.

${ }^{53}$ Ibid., para. 35.

${ }^{54}$ Ibid., para. 36.

${ }^{55}$ Dispute regarding Navigational and Related Rights, op. cit. para. 48.
} 
The Court used the text of corresponding bilateral treaties to find information for interpreting them and in this way replying to the raised questions. In occasions when the text was mute, the Court turned to other evidences. For example, as the Treaty of Limits did not contain any information on the issue whether the local population on the Costa Rican bank of the San Juan River were entitled to fish for subsistence purpose, the Court explored the existence of a local customary rule as a title of the right.

On the other hand, when the Court had begun interpretation by using the text of a treaty, mostly the Court used also other manifestations of intent of the parties or their understanding of text or of circumstances that influence their intent or understanding. Clarifying the words "con objetos" the Court used together with the text of the Treaty of Limits, the 1857 Treaty of Peace and the official English translations of the Treaty of Limits that the parties used in arbitration proceedings in 1887. The answer to the question on the existence of the right of Costa Rica of non-commercial navigation of local population for meeting everyday needs was searched for not only in the whole text of the Treaty of Limits but also in the historical background of the Treaty and the geography of the area. The Court interpreted text of Article 41 (a) of the Statute of the River Uruguay by referring to the relevant general practice of the States and to general principles. Assembling information for replying to the question whether the responded respected its obligation under Article 11 (1) of the Interim Accord of 13 September 1995, the Court explored the text of the Accord, UN Security Council resolution 817 (1993), the "Memorandum on 'Practical Measures' Related to the Interim Accord," the practice in the implementation of the Accord and considered the need for an investigation of the preparatory work. Exceptionally, the Court used exclusively text of Articles 1 and 41(a) of the Statute of the River Uruguay to consider Nicaragua's jurisdictional claim that these Articles incorporate in the Statute other environmental treaties and rules of general international law.

In Application of the Interim Accord the Court rejected to explore extensively the travaux preparatoires submitted by the parties. The Court was authorized to do that by Article 32 of the Vienna Convention. According to Article 32 if the application of Article 31 results in a clear meaning, the application of the supplementary means form Article 32 is not necessary. In the judgment the Court informed that it had applied the Articles 31 and 32 thinking probably that the consideration of a need for the application of supplementary means and coming to the conclusion that there was no such need was the application of Article 32.

There is no other information in the three judgments that the Court rejected for consideration any evidence relevant for an interpretation submitted by a party. It may be presumed that the Court considered all evidence submitted by the parties for the purpose of interpretation except the travaux preparatoires in Application of the Interim Accord. Some of considered evidences can be classified under 
Article 31 . Some can be characterized as the supplementary means, such as the historical background of the Treaty of Limits and the geography of the area or the 1857 Peace Treaty. Having in view that methods dealing with the evidences resulted in harmonious information, the issue or relative significance of any of the evidence is not of importance.

It might be concluded that the analysis of the three cases of interpretation of bilateral treaties did not disclose a remarkable difference in respect to the application of rule expressed Article 31 (1) of the Vienna Convention that relates to the text of a treaty.

\subsection{Specific characteristics of the cases determining the relevance of factors used in the interpretation}

The three considered cases differ by specific characteristics that might have some bearing on the range of factors used in interpretation.

The dispute between Greece and Macedonia related to a very specific and temporary agreement. By its object the Interim Accord is unique and does not adhere to any broader field of international law. The obligations in the Accord are specific and concrete. The arbitral clause in the Interim Accord excluded the jurisdiction of the Court to consider the dispute concerning the name of Macedonia. The Court was asked to answer a single question: whether Greece violated Article 11 (1) of the Interim Accord. Such circumstances limit factors of relevance for interpretation to manifestations of intention of the parties and to expressions of their understanding of the text of the Accord. The Interim Accord is foreseen as relatively short living instrument. Hence the issue of intertemporality cannot appear.

The two bilateral treaties, interpreted in two other cases, have established permanent international régimes. One of them related to the Uruguay River belongs by its object to international environmental law. Both include very broad provisions. In both cases the Court was invited to address by interpretation numerous differences. Such circumstances dictated a broader range of factors relevant for interpretation that cover also general rules of international law and general practice of States.

It is understandable that the raised question may determine relevance of the factors for interpretation. Those relevant are only these factors that extend some information useful to the answer. The two mentioned cases illustrate what is said. If a question was addressed by a particular provision, the Court focused on it. If no one particular provision addressed the question, the Court investigated the text of a treaty as a whole or factors beyond the text of a treaty.

The Navigational and Related Rights case has disclosed that the way in which a party argues a claim may shape the way by which the Court interprets a treaty. 
The Court found the title of the right of non-commercial navigation in favour of Costa Rica in the text of the Treaty of Limits as a whole, in particular in preamble and in Articles I and II in conjunction with the historical background of the Treaty and the geography of an area. The quoted provisions of the Treaty do not say anything explicitly on the right of non-commercial navigation. A more reliable source of information was the unbroken practice of non-commercial navigation lasting from the conclusion of the Treaty in 1858 without any objection of Nicaragua until 1980 when non-commercial navigation of a Costa Rican official vessel Nicaragua hindered. The situation concerning the right of non-commercial navigation was comparable with the situation concerning the right of Costa Rica that the local population use the river for subsistence fishing. The practice of subsistence fishing existed already at the time of the conclusion of the Treaty and had continued without being objected to by Nicaragua. The Court found the title of the right to subsistence fishing in the local custom and the title of the right of non-commercial navigation implied in the Treaty. The difference can be explained by the arguments of the parties. Costa Rica claimed that the right of non-commercial navigation had its title in Article VI and that the right to subsistence fishing had its title in local custom. The Court rejected the claim that the right was based in Article VI but found its titles implied in the text of the Treaty and confirmed the existence of a local custom.

\section{CONCLUSIONS}

The text studied interpretation of three different bilateral treaties: the 1858 Treaty of Limits between Costa Rica and Nicaragua, the 1975 Statute of the River Uruguay between Argentina and Uruguay and the 1995 Interim Accord between Greece and Macedonia. The first two treaties have established permanent international régimes.

The Treaty of Limits extends sovereignty of Nicaragua over the San Juan River and guarantees the right of Costa Rica of free navigation for commercial purpose on the river. The parties disputed the extent of the right to free navigation for commercial purposes, on the extent of regulatory powers that Nicaragua has over the right as a sovereign on the river, as well as on the existence of the right of non-commercial navigation for the meeting daily needs of the local population and on the existence of the right of that population to fishing for subsistence purposes.

The substance of dispute between Argentina and Uruguay was whether authorization issued by Uruguay for building pulp mills on the bank of the River Uruguay was in accordance with international law. The dispute was complex and included jurisdictional difference and differences related to procedural and substantive provision of the Statute. 
Macedonia and Greece were in dispute as to whether Greece violated its obligation under Article 11 (1) of the Interim Accord by obstructing Macedonia's admission to NATO. In comparison with the first two cases that one involved a small number of differences.

The Court applied Article 31 (1) of the Vienna Convention in all three cases in a similar way. An analysis of the text of a treaty was the first and main means of interpretation. The Court used a literal and grammatical analysis of the relevant provision, principle of l'effet utile, context, object and purpose.

Differences between the cases exist in respect to employment of other means of interpretation from Articles 31 and 32 of the Vienna Convention. From the ambit of Article 31 the Court used an agreement related to the conclusion of the interpreted treaty and subsequent practice in the application of the treaty in the Application of the Interim Accord case. In the Pulp Mills case the Court used a general rule and principles of international law form the realm of Article 31. In Navigational and Related Rights the Court used supplementary means of interpretation provided for in Article 32 such as a treaty that preceded the interpreted treaty, historical background of the interpreted treaty, the geography of the area and general practice of State etc. In Pulp Mills and Navigational and Related Rights the Court introduced the factor of intertemporality in interpretation. In these cases the Court ascertained not only the expressed intent of the parties but also presumed or implied intent.

The difference in the employment of various means of interpretation under Articles 31 and 32 of the Vienna Convention might be explained by the specific characteristics of the treaties. The 1995 Interim Agreement was unique by its object - the mitigating of harsh consequences that the Greek disagreement with the constitutional name of Macedonia produced to their bilateral relations and to the international position of Macedonia. By its nature the object does not adhere to any particular field of international law whose general provisions may be applicable between the parties to help in interpretation. Therefore, the range of means of interpretation is limited to those that express intention of the parties and those that manifest their understanding of the text. Opposite to that, disputed part of the 1975 Statute of the River Uruguay belongs by its object to international environmental law and its general customary rules applicable between the parties could have substantiated some general provisions of the Statute.

Beyond the specific characteristics of the considered treaties, the question submitted to the Court may determine the relevance of the factors of interpretation. It is understandable that only those means of interpretation are relevant that offer information useful for the answer to the submitted question. It seems also that the way by which the parties articulate their claims may influence the way by which the Court interprets a treaty. 
Др Родољуб М. Еӣински, редовни йрофесор

Универзииетеи у Новом Саду

Правни факулиетеи у Новом Саду

R.Etinski@pf.uns.ac.rs

\section{Тумачење неких билатералних уговора од стране Међународног суда правде}

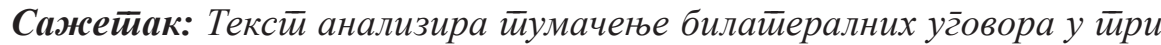
ирредметиа које је рещио Међународни суд ирравде у иериоду од 2009. до 2011. године. Како се ииумачење обавља ирименом истих ирравила која су изложена у члановима 31 и 32 Бечке конвениије о ирраву уг̄овора, оно укључује истиа или слична средстива йумачена. Сиецифичне каракиееристикке сваког̄ случаја,

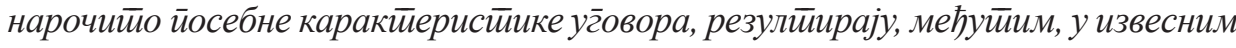
разликама. Средсиива йумачења, корищћена у йумачењу угоовора који уређује

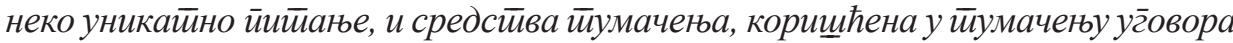
чији ирредмети ирийада класи ирредетиа неке областии међународног̄ ирава, се делимично разликују.

Кључне речи: ииумачење; билайерални уг̄овори.

Датум пријема рада: 12.12.2017. 